\title{
Pengembangan Lembar Kerja Siswa Berbasis Kontekstual Untuk Meningkatkan Hasil Belajar Matematika di Sekolah Dasar
}

\author{
Aswarliansyah \\ Prodi PGSD, STKIP-PGRI Lubuklinggau, Sumatera Selatan, Indonesia \\ E-mail: aswarliansyah55@gmail.com
}

\begin{abstract}
Abstrak
Permasalahan dalam penelitian adalah penyajian materi lembar kerja siswa yang digunakan guru secara langsung dan abstrak sehingga isinya tidak menuntut siswa untuk bertanya, menemukan sendiri dan mengkontruksikan sendiri. Penelitian ini bertujuan untuk mendiskripsikan lembar kerja siswa berbasis kontekstual pelajaran Matematika kelas V Sekolah Dasar yang praktis dan efektif untuk meningkatkan hasil belajar. Penelitian ini merupakan penelitian pengembangan menurut Borg dan Gall, namun pada penelitian ini diadaptasi 6 langkahlangkah penelitian pengembangan mengingat keterbatasan waktu, biaya dan tenaga. Langkah-langkah penelitian ini terdiri dari (1) penelitian dan pengumpulan informasi, (2) perencanaan, (3) pengembangan produk awal, (4) uji coba terbatas, (5) revisi produk awal, dan (6) uji coba lapangan. Pengumpulan data melalui lembar respon siswa dan instrumen soal. Tingkat kepraktisan lembar kerja siswa berbasis kontekstual setelah dilakukan analisis respon siswa diketahui bahwa rata-rata persentase respon siswa adalah $80 \%$. Data menunjukkan bahwa lembar kerja siswa berbasis kontekstual praktis untuk digunakan. Sedangkan keefektifan lembar kerja siswa dilakukan analisis melalui korelasi respon belajar belajar dan hasil belajar siswa. Hasil analisis data menunjukkan bahwa terjadi hubungan sebesar 0,766 dengan kriteria efektif.
\end{abstract}

Kata kunci: pengembangan, LKS, kontekstual. matematika

\section{Abstract}

The problem this research is the presentation of student worksheet material used by the teacher directly and abstractly so that the content does not require students to ask questions, discover for themselves and construct themselves. This study aims to describe a practical and effective contextual-based student worksheet for fifth grade elementary school mathematics to improve learning outcomes. This research is a development research according to Borg and Gall, but in this study, 6 steps of development research were adapted considering the limitations of time, cost and energy. The research steps consisted of: (1) research and information gathering, (2) planning, (3) initial product development, (4) limited trials, (5) initial product revisions, and (6) field trials. Collecting data through student response sheets and question instruments. The level of practicality of contextual-based student worksheets. After analyzing student responses, it is known that the average percentage of student responses is $80 \%$. The data show that contextual-based student worksheets are practical to use. While the effectiveness of student worksheets is analyzed through the correlation of learning responses and student learning outcomes. The results of data analysis showed that there was a relationship of 0.766 with the effective criteria.

Keywords: development, student worksheets, contextual, mathematics

Copyright (c) 2020 Aswarliansyah

$\triangle$ Corresponding author

Address : Jl. Mayor Toha, Kel. Air Kuti

Email : aswarliansyah55@gmail.com

ISSN 2580-3735 (Media Cetak)

Phone : 081377532275

ISSN 2580-1147 (Media Online)

DOI: https://doi.org/10.31004/basicedu.v4i4.509 


\section{PENDAHULUAN}

Pembelajaran matematika adalah suatu proses belajar mengajar yang dibangun oleh guru untuk mengembangkan kreatifitas siswa yang dapat meningkatkan kemampuan berfikir, berargumentasi, dan memberikan kontribusi penyelesaian masalah dalam sehari-hari. Sebagaimana yang diungkapkan Suherman (Amsari, 2018:54), salah satu tujuan pembelajaran adalah mempersiapkan siswa menggunakan matematika dan pola pikir matematika dalam kehidupan sehari-hari dan dalam mempelajari ilmu pengetahuan. Berdasarkan hasil Trend in International Mathematics and Science Study atau TIMMS tahun 2015 (Puspendik Kemendikbud. 2015), Indonesia menduduki peringkat ke 45 dari 50 negara.

Hasratuddin, (2010:19) bahwa praktek pembelajaran di sekolah-sekolah yang berlangsung selama ini, dan hampir di semua jenjang pendidikan, pada umumnya berlangsung satu arah, yaitu guru sebagai pusat pembelajaran (teacher centered). Nurhayati, (2013:51) peran guru dalam pembelajaran bukan hanya menguliahi, menerangkan atau upaya-upaya sejenis untuk memindahkan pengetahuan matematika pada siswa, tetapi membantu siswa untuk menciptakan kontruksi-kontruksi. Hal ini juga ditemukan pembelajaran yang kurang memberi kegiatan pembelajaran secara langsung (Fardian dalam Sumianto, 2018:50). Fauzan (dalam Sembiring, 2010:12) juga menyampaikan bahwa permasahan terbesar pembelajaran matematika adalah menyajikan matematika sebagai produk jadi, siap pakai, abstrak dan diajarkan secara mekanistik (guru mendiktekan rumus dan prosedur kepada siswa). Dengan demikian, proses pembelajaran yang terjadi masih berpusat pada guru, yang menyebabkan siswa menjadi pasif saat belajar.

Berdasarkan observasi dibeberapa sekolah di kecamatan Lubuklinggau Selatan II bahwa guru mengajar menggunakan lembar kerja siswa (LKS). Lembar kerja siswa yang digunakan adalah LKS terbitan CV Grafika Dua Tujuh. Isi materi dari LKS yang digunakan sebenarnya sudah lengkap namun kurang mengaitkan dengan kehidupan sehari-hari siswa. Isinya tidak menuntut siswa untuk bertanya, menemukan sendiri dan mengkontruksikan sendiri. Penyajian materi kurang menarik dan susah dipahami. Materi disajikan secara langsung dan abstrak. Misalnya pengertian dari kubus, langsung ada didalam LKS tersebut begitu juga dengan sifat-sifat kubus langsung disajikan dalam LKS. Hal ini menyebabkan pola belajar siswa adalah pola belajar dengan hanya membaca dan mendengarkan guru yang menjelaskan. Hasilnya siswa hanya mengerti secara teori tapi secara pemahaman siswa lemah, sehingga materi yang didapat akan cepat hilang dalam ingatannya.

Berdasarkan wawancara dengan siswa mereka mengatakan bahwa kalimat dalam LKS yang digunakan guru banyak yang terlalu panjang sehingga sulit mereka pahami. Gambar-gambar yang disajikan dalam LKS banyak tidak siswa ketahui. Pembelajaran yang terjadi membosankan karena biasa hanya mendengarkan penjelasan dari guru lalu kemudian mengerjakan soal latihan dalam LKS. Tidak pernah menggunakan media 
pembelajaran yang dekat dengan lingkungan sekolah siswa.

Menurut Komalasari, (2010:7) CTL adalah pendekatan pembelajaran yang mengaitkan antara materi yang dipelajari dengan kehidupan nyata siswa sehari-hari, praktis dalam lingkungan keluarga, sekolah, masyarakat maupun warga negara, dengan tujuan untuk menemukan makna materi tersebut bagi kehidupannya. Penjelasan lebih lanjut dikemukakan oleh Komalasari, (2010:13) bahwa karakteristik pembelajaran CTL meliputi pembelajaran yang menerapkan konsep keterkaitan (relating), konsep pengalaman langsung (experiencing), konsep aplikasi (applying), konsep kerja sama (cooperating), konsep pengaturan diri (self-regulating) dan konsep penilaian autentik (autentic assesment). Jurnal penelitian Sugandi, A., (2017:135) menyatakan bahwa pembelajaran CTL berpengaruh signifikan terhadap pemahaman konsep.

Pembelajaran yang mengaitkan langsung dengan kehidupan sehari-hari siswa tentu akan menyenangkan dan mudah dipahami oleh siswa. Seorang guru harus mampu memanfaatkan bendabenda yang ada di lingkungan sekitar siswa untuk dijadikan media pembelajaran. Hal ini selaras dengan pendapat Mulyasa, (2014:22) bahwa dalam pengembangan fasilitas dan sumber belajar, guru di samping harus mampu membuat alat pembelajaran dan alat peraga, juga berinisiatif mendayagunakan lingkungan sekitar sekolah sebagai sumber belajar yang konkret. Maka dari itu penting untuk dikembangkan lembar kerja siswa yang menarik dan mengaitkan materi dengan kehidupan sehari-hari siswa untuk menciptakan pembelajaran yang menyenangkan dan tidak membosankan.

Berdasarkan uraian diatas, peneliti ingin mengembangkan Lembar Kerja Siswa berbasis kontekstual pada pelajaran matematika kelas V.

\section{METODE}

Metode penelitian ini adalah penelitian pengembangan. Menurut Sugiyono (2016:29) perencanaan dan penelitian pengembangan merupakan metode untuk mengembangkan produk baru, model, prosedur, teknik, dan permasalahan yang spesifik. Produk yang dikembangkan dalam penelitian ini adalah lembar kerja siswa berbasis kontekstual pada pelajaran matematika kelas V. Model pengembangan dalam penelitian ini diadaptasi dari model Borg dan Gall.

Lembar kerja siswa yang telah di vallidasi ahli ini di lakukan uji coba lapangan pada tanggal 30 April 2018 sampai dengan 31 Mei 2018 di SD Negeri 55 Lubuklinggau, SD Negeri 56 Lubuklinggau dan SD Nergeri 59 Lubukinggau. Subjek penelitian ini adalah siswa kelas V SD Negeri 55 Lubuklinggau sebanyak 24 siswa yang terdiri dari 10 laki dan 12 perempuan, SD Negeri 56 Lubuklinggau sebanyak 26 siswa yang terdiri dari 10 laki-laki dan 16 perempuan dan SD Negeri 59 Lubuklinggau sebanyak 26 siswa yang terdiri dari 12 laki-laki dan 14 perempuan.

Instrumen yang digunakan untuk mengukur kepraktisan dan keefektifan LKS berbasis kontekstual adalah angket respon siswa dan instrumen penilaian. Analisis kepraktisan lembar kerja siswa dilakukan untuk mengetahui tingkat 
1137 Pengembangan Lembar Kerja Siswa Berbasis Kontekstual Untuk Meningkatkan Hasil Belajar Matematika di Sekolah Dasar- Aswarliansyah

DOI: https://doi.org/10.31004/basicedu.v4i4.509

kepraktisan LKS berbasis kontekstual pada pelajaran matematika kelas $\mathrm{V}$ yang dikembangkan. Instrumen yang digunakan untuk menganalisis kepraktisan LKS adalah lembar angket keterlaksanaan pembelajaran yang diambil dari instrumen respon siswa. Data yang diperoleh dari lembar angket respon siswa dianalisis dengan menghitung rata-rata respon belajar siswa. Analisis keefektifan LKS dilakukan dengan menentukan korelasi data respon belajar siswa dan hasil belajar siswa.

\section{HASIL DAN PEMBAHASAN}

\section{Hasil Analisis Kepraktisan LKS}

Analisis kepraktisan dihitung dari data respon siswa. respon siswa diambil dari 3 sekolah yang menjadi tempat penelitian yaitu sebanyak 76 siswa yang terdiri dari 32 laki-laki dan 44 perempuan. Analisis kepraktisan dilakukan untuk melihat kepraktisan LKS berbasis kontekstual pada pelajaran matematika kelas V. Hasil analisis kepraktisan LKS yang dilakukan peneliti dinyatakan dalam Tabel 1.

Hasil analisis respon belajar siswa dari 76 siswa adalah dengan jumlah skor total 5418 dan persentasenya $89,91 \%$ yang berkriteria sangat praktis. Maka dengan demikian LKS berbasis kontekstual pada pelajaran matematika kelas $\mathrm{V}$ sangat praktis untuk digunakan.

\section{Hasil Analisi Keefektifan LKS}

Lembar kerja siswa dikatakan efektif untuk meningkatkan hasil belajar jika tingkat hubungan kepraktisan dan hasil belajar siswa minimal tinggi $(0,700-0,900)$. Hasil analisis korelasi hubungan hasil belajar siswa dengan respon belajar siswa pada LKS berbasis kontekstual dinyatakan pada Tabel 2

Tabel 1. Hasil analisis kepraktisan LKS

\begin{tabular}{|c|c|c|c|}
\hline Pernyataan ke & $\begin{array}{c}\text { Jumlah } \\
\text { Skor }\end{array}$ & Persentase & Kriteria \\
\hline 1 & 274 & $90 \%$ & $\begin{array}{l}\text { Sangat } \\
\text { Praktis }\end{array}$ \\
\hline 2 & 271 & $89 \%$ & $\begin{array}{l}\text { Sangat } \\
\text { Praktis }\end{array}$ \\
\hline 3 & 228 & $75 \%$ & Praktis \\
\hline 4 & 243 & $89 \%$ & $\begin{array}{l}\text { Sangat } \\
\text { praktis }\end{array}$ \\
\hline 5 & 243 & $80 \%$ & $\begin{array}{l}\text { Sangat } \\
\text { Praktis }\end{array}$ \\
\hline 6 & 232 & $76 \%$ & Praktis \\
\hline 7 & 238 & $78 \%$ & Praktis \\
\hline 8 & 238 & $78 \%$ & Praktis \\
\hline 9 & 268 & $88 \%$ & $\begin{array}{l}\text { Sangat } \\
\text { Praktis }\end{array}$ \\
\hline 10 & 270 & $89 \%$ & $\begin{array}{l}\text { Sangat } \\
\text { praktis }\end{array}$ \\
\hline 11 & 232 & $76 \%$ & Praktis \\
\hline 12 & 238 & $78 \%$ & Praktis \\
\hline 13 & 228 & $75 \%$ & Praktis \\
\hline 14 & 228 & $75 \%$ & Praktis \\
\hline 15 & 238 & $78 \%$ & Praktis \\
\hline 16 & 232 & $76 \%$ & Praktis \\
\hline 17 & 244 & $80 \%$ & $\begin{array}{l}\text { Sangat } \\
\text { Praktis }\end{array}$ \\
\hline 18 & 244 & $80 \%$ & $\begin{array}{l}\text { Sangat } \\
\text { praktis }\end{array}$ \\
\hline 19 & 232 & $76 \%$ & Praktis \\
\hline 20 & 247 & $81 \%$ & $\begin{array}{l}\text { Sangat } \\
\text { praktis }\end{array}$ \\
\hline Rata-rata & 4868 & $80 \%$ & $\begin{array}{l}\text { Sangat } \\
\text { Praktis }\end{array}$ \\
\hline
\end{tabular}

Tabel 2. Hasil Analsis Hubungan Respon Belajar Siswa dengan Hasil Belajar Siswa

\begin{tabular}{|l|c|c|c|c|}
\hline \multicolumn{2}{|c|}{ Variabel } & Signifikan & Korelasi & Kriteria \\
\hline $\begin{array}{l}\text { Respon } \\
\text { Belajar }\end{array}$ & $\begin{array}{c}\text { Hasil } \\
\text { Belajar }\end{array}$ & 0,000 & 0,766 & Efektif \\
\hline
\end{tabular}

Ada hubungan yang signifikan antara hasil belajar siswa dengan respon belajar siswa (Tabel 2). Hasil analisis korelasi hasil belajar siswa dan 
respon belajar siswa yang diambil dari 76 siswa adalah 0,766. Dengan demikian korelasi yang terjadi berkriteria efektif. Muchtadi, Hartono dan Oktaviana (2017:54) menyatakan bahwa hubungan hasil belajar dan respon mahasiswa atau setiap peningkatan respon mahasiswa sebesar satu satuan, maka hasil belajar mahasiswa akan meningkat 0,49 satuan. Respon mahasiswa memberikan kontribusi yang berarti pada hasil belajar mahasiswa. Dengan demikian LKS berbasis kontekstual efektif untuk digunakan pada pembelajaran.

\section{Pembahasan}

Lembar kerja siswa adalah dokumen tertulis yang mencakup kegiatan untuk membangun aktivitas siswa selama pelajaran. LKS berbasis kontekstual yang dikembangkan yaitu LKS yang mengandung kegiatan menanya, menemukan, kelompok belajar, pemodelan, menyimpulkan dan penilaian.

\section{Kepraktisan LKS berbasis Kontekstual}

Menurut Rohaeti, (2010:21) LKS dikatakan praktis apabila memenuhi syarat-syarat didaktik, syarat kontruksi dan syarat teknis. Syarat didaktik mengatur tentang penggunaan LKS yang lebih menekankan pada proses untuk menemukan konsep dan yang terpenting dalam LKS ada variasi stimulus melalui berbagai media dan kegiatan siswa. Syarat kontruksi berhubungan dengan penggunaan bahasa, susunan kalimat, kosa kata dan kejelasan dalam LKS. Syarat teknis menekankan pada tulisan, gambar, penampilan dalam LKS.
Pemanfaatan media yang ada disekitar siswa berpengaruh positif pada keaktifan belajar siswa. Hal ini selaras dengan Winarni, (2018:84) pemanfaatan pembelajaran kontekstual akan menciptakan ruang kelas yang didalamnya siswa akan menjadi peserta aktif bukan hanya pengamat yang pasif, dan bertanggung jawab terhadap belajarnya.

Pembelajaran pada uji coba lapangan LKS berbasis kontekstual yang dikembangkan peneliti terlaksana dengan baik dan siswa aktif dalam belajar. Menurut Gitriani, dkk (2018:46) LKS berbasis kontekstual praktis digunakan oleh siswa sehingga pembelajaran dapat terlaksana dengan baik, aktif dan kreatif. Uji kepraktisan LKS berdasarkan analisis melalui respon belajar siswa. LKS berbasis kontekstual praktis untuk digunakan dalam pembelajaran.

\section{Keefektifan LKS berbasis Kontekstual}

Kegiatan-kegiatan dalam LKS berbasis kontekstual menjadikan siswa aktif dan termotivasi dalam belajar dan pembelajaran yang terjadi tidak monoton. Hal ini selaras dengan Trianto dalam Gitriani, dkk (2018:47) bahwa LKS berguna untuk mengoptimalkan pemahaman siswa dengan kegiatan-kegiatan yang mendasar sesuai dengan tujuan dan indikator pencapaiannya. Unsur-unsur yang terkandung dalam LKS berbasis kontekstual yang dikembangkan adalah menanya, kelompok belajar, penemuan, pemodelan, menyimpulkan dan penilaian.

Kegiatan menanya pada LKS berbasis kontekstual yang dikembangkan adalah siswa menanyakan hal-hal yang belum diketahui tentang 
kubus, balok dan tabung dengan melihat langsung media yang disediakan yaitu rubik, kotak snack, kardus, penghapu dan kaleng susu. Kegiatan menanya menyebabkan siswa aktif dalam belajar, menumbuhkan mental atau keberanian untuk berbica dan bertanya serta menggali pemahaman siswa.

Kegiatan pada LKS yang dikembangkan dilakukan dalam kelompok belajar. Kegiatan kelompok belajar yang dilakukan yaitu siswa bersama-sama melakukan pengamatan, penemuan dan penarikan kesimpulan dari hasil kegiatan kelompok. Kegiatan kelompok belajar pada LKS berbasis kontekstual yang dikembangkan menyebabkan siswa saling berbagi ide-ide, bekerja sama untuk memecahkan suatu permasalahan, memberikan kemudahan bagi siswa dalam pemahaman materi.

Kegiatan penemuan pada LKS yang dikembangakan adalah siswa melakukan penemuan unsur-unsur dari kubus, balok dan tabung. Penemuan unsur-unsur tabung dilakukan melalui pengamatan terhadap media kontekstual. Kegiatan penemuan menyebabkan siswa aktif dalam belajar, menumbuhkan motivasi belajar siswa dan kemandirian belajar siswa.

Melalui kegiatan penemuan menyebabkan siswa dituntut untuk belajar mandiri untuk memperoleh dan memahami suatu pengetahuan. Penemuan yang dilakukan siswa menyebabkan pemahaman dan pengetahuan yang diterima siswa lebih tahan lama dalam memori siswa. Hal ini selaras dengan Arnold dalam Jannah (2016:120) menyatakan bahwa pembelajaran inkuiri ilmiah membantu siswa memperoleh wawasan bagaimana pengetahuan ilmiah diperoleh.

Kegiatan menyimpulkan pada lembar kerja siswa berbasis kontekstual yang dikembangkan membuat siswa mampu untuk mengkontruksi suatu materi pembelajaran dan membangun pengetahuannya sendiri. Penyimpulan dilakukan siswa berdasarkan hasil pengamatan. Hal ini selaras dengan pendapat Bruner dalam Gitriani, (2018:47) bahwa guru harus mengarahkan atau memandu siswa-siswanya sehingga mereka dapat membangun pengetahuannya secara madiri, bukan karena diberitahu atau diajari melalui memori hapalan.

Unsur pemodelan pada LKS berbasis kontekstual dituangkan pada kegiatan pengamatan media pembelajaran yang digunakan. Media yang digunakan pada LKS berbasis kontekstual adalah benda-benda yang diketahui oleh siswa dan ada disekitar lingkungan siswa. kegiatan pemodelan yang dilakukan siswa menumbuhkan kerjasama siswa. Pengamatan media secara langsung yang dilakukan oleh siswa menyebabkan pembelajaran lebih bermakna dan menyenangkan, karena siswa dapat menemukan dan memahami secara nyata apa yang dipelajari. Winarni (2018:83) menyatakan bahwa siswa akan bekerja keras mencapai tujuan pembelajaran, mereka menggunakan pengalaman dan pengetahuan sebelumnya untuk membangun pengetahuan baru.

Unsur-unsur kegiatan lembar kerja siswa berbasis kontekstual yang dikembangkan menyebabkan terciptanya pembelajaran yang menarik dan menyenangkan sehingga respon belajar siswa menunjukkan LKS yang 
dikembangkan praktis dan efisien. Respon belajar siswa ini berpengaruh pada hasil belajar siswa. Keefektifan lembar kerja siswa berbasis kontekstual dianalisis dengan melihat korelasi respon belajar siswa dan hasil belajar siswa. Semakin tinggi respon belajar siswa maka akan semakin tinggi hasil belajar siswa. Hal ini selaras dengan Muchtadi (2017:52) terdapat hubungan antara respon belajar siswa dan hasil belajar mahasiswa, setiap peningkatan respon mahasiswa sebesar satu satuan, maka hasil belajar mahasiswa akan meningkat sebesar 0,49 satuan.

\section{SIMPULAN}

Berdasarkan analisis data hasil penelitian, maka dapat disimpulkan bahwa LKS berbasis kontekstual pada pelajaran matematika kelas V dikategorikan praktis dan efektif yang didukung oleh data sebagai berikut:

1. Pada tahap uji coba lapangan diperoleh analisis data hasil respon belajar siswa. Respon belajar siswa yang dikembangkan sebanyak 20 pernyataan. Analisis yang dilakukan diperoleh sebesar $80 \%$. Maka dapat disimpulkan bahwa LKS berbasis kontekstual sangat praktis untuk digunakan.

2. Data hasi analisis korelasi respon belajar siswa dengan hasil belajar siswa adalah 0,766 , dengan taraf signifikan 0,01 . Hal ini menunjukkan bahwa terjadi hubungan yang signifikan antara respon belajar siswa dan hasil belajar siswa. dengan demikian disimpulkan bahwa LKS berbasis kontekstual efektif untuk digunakan.

\section{UCAPAN TERIMA KASIH}

Selama penulisan artikel ini, penulis telah banyak mendapatkan bimbingan, motivasi, saran dan nasihat dari berbagai pihak. Dengan segala kerendahan hati penulis mengucapkan terimakasih yang sebesar-besarnya kepada :

1. Prof. Dr. Agus Sutanta, M.Ed. Ph.D., dan Dr. Hadiwinarto, M.Psi., yang telah memberikan bimbingan serta arahan sehingga penelitian ini dapat terselesaikan.

2. Bapak dan Ibu Kepala Sekolah, Guru Kelas IV, V dan VI serta Staf Sekolah Dasar Negeri di wilayah kecamatan Lubuklinggau Selatan II.

3. Seluruh pihak yang telah banyak membantu baik secara langsung maupun tidak langsung yang tidak dapat disebutkan satu persatu.

Semoga amal baik yang diberikan kepada penulis mendapatkan balasan dari Allah SWT. Penulis berharap semoga penelitian ini dapat bermanfaat bagi pembaca dan pihak-pihak yang terkait khususnya dalam pengembangan ilmu pengetahuan.

\section{DAFTAR PUSTAKA}

Amsari. (2018). Implikasi Teori Belajar E.Thorndike (Behavioristik) Dalam Pembelajaran Matematika. Basicedu, 2(2), 54.

Endang Widi Winarni. (2018). Teori dan Praktik Penelitian Kuntitatif, Kualitatif, PTK dan $R \& D$ (1st ed.). Bumi Aksara.

Gitriani, R., Aisah, S., Hendriana, $\mathrm{H}$ dan Herdiman, I. (2018). Pengembangan Lembar Kerja Siswa Berbasis Pendekatan Kontekstual pada Materi Lingkaran untuk Siswa SMP. Jurnal Review Pembelajaran Matematika, 3(2), 46. 
1141 Pengembangan Lembar Kerja Siswa Berbasis Kontekstual Untuk Meningkatkan Hasil Belajar Matematika di Sekolah Dasar- Aswarliansyah

DOI: https://doi.org/10.31004/basicedu.v4i4.509

Hasratuddin. (2010). Meningkatkan Kemampuan Berpikir Kritis Siswa SMP Melalui Pendekatan Matematika Realistik. Jurnal Pendidikan Matematika, 4(2), 19.

Jannah, L., Nur, M. dan S. (2016). Desain Bahan Ajar Materi Gelombang dan Bunyi Model Inkuiri Terbimbing Untuk Melatih Keterampilan Proses sains Siswa SMP. Jurnal Pendidikan Sains, 6(1), 120.

Komalasari. (2010). Pembelajaran Kontekstual. PT Refika Aditama.

Muchtadi; Hartoyo; Oktarina. (2017). Hubungan Aktvitas dan Respon Terhadap Hasil Belajar Program Linier Melalui Penerapan Pembelajaran Genius Learning Pada Program Studi Pendidikan Matematika. Jurnal Pendidikan Sains Dan Matematika, 5(1), 54.

Mulyasa. (2014). Pengembangan dan Implementasi Kurikulum 2013. PT Remaja Rosdakarya.

Nurhayati. (2013). Pengembangan Bahan Ajar Turunan Fungsi Melalui Pendekatan Konstruktivisme Di Sekolah Menengah Atas. EDUMAT, 4(8), 511.

Rohaeti, E. W. dan E. P. T. R. (2010). Kualitas Lembar Kerja Siswa. Jurnal Inovasi Pendidikan, 10(1), 21.

Sembiring. (2010). Pendidikan Matematika Realistik Perkembangan dan Tantangan. Indo $M S$-JME, $1,12$.

Sugandi, A., S. dan I. (2017). Pengaruh Pembelajaran Ctl Berbasis Entrepreneurship Terhadap Minyak Bumi. Mandalanursa.

Sumianto. (2018). Penerapan Pendekatan Matematika Realistik (PMR) Untuk Meningkatkan Hasil Belajar Matematika Siswa Kelas V Al-Azim SDIT Raudhatur Rahmah Pekanbaru. Basicedu, 2(1), 50.

Winarni, E. W. (2018). Pendekatan Ilmiah dalam Pembelajaran Kreatif dan Inovatif. FKIP UNIB. 